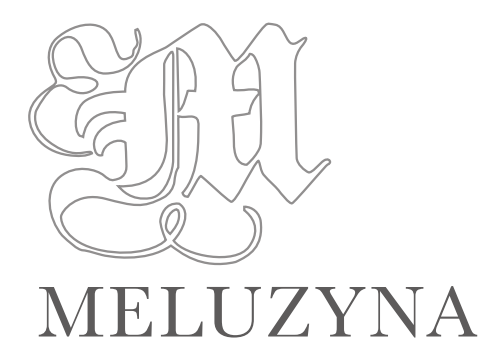

ISSN 2449-7339

2 (5) (2016) I Rocznik III

DOI: $10.18276 / \mathrm{me} .2016 .2-06$

INEDITA

Barbara Zając*

Uniwersytet Marii Curie-Skłodowskiej

\title{
Edycja krytyczna Miesięcy dwunastu z swoich okoliczności opisania Jana Gawińskiego
}

\section{Wstęp}

Twórczość Jana z Wielomowic Gawińskiego (ok. 1622-1684), pomijana po II wojnie światowej raczej milczeniem przez historyków literatury do lat 90. ubiegłego wieku (np. Czesław Hernas w syntezie Barok nie poświęcił poecie nawet wzmianki) ${ }^{1}$, od dwudziestu lat jest przedmiotem bardziej intensywnych badań literaturoznawców (Sproede, 1990; Chemperek, 2005; Głażewski, 2008; Kroczak, 2008; Rot-Buga, 2009), także w kontekście innych zagadnień, gdzie osoba i twórczość są jednak szerzej wzmiankowane (Nowicka-Jeżowa, 1988; Nowicka-Jeżowa, 1992; Walińska, 2003; Piskała, 2010; Barłowska, 2014). Powstają także edycje krytyczne (Chemperek, 2000, 2009; Chemperek, Walecki, 2003; Głażewski, 2005; Rot, 2007).

Biografia Gawińskiego, dość niezwykła na tle życiorysów innych poetów polskich XVII wieku, została odtworzona już na początku XX stulecia przez Leszka Marię Dziamę (1905) i uzupełniona przez współczesnego monografistę poety (Chemperek, 2005, s. 21-34). Dla niniejszego wprowadzenia do lektury Miesięcy dwunastu z swoich okoliczności opisania istotny jest fakt, że Jan z Wielomowic, z dużą dozą prawdopodobieństwa uzurpujący sobie szlachectwo, mieszkał od 1650 roku w Krakowie, dwukrotnie żonaty był z tamtejszymi mieszczkami i na świat „wieśnych wczasów i pożytków” patrzył oczyma mieszczanina, estety wykształconego na literatu-

\footnotetext{
e-mail autorki: bar.zajac94@gmail.com

1 Wyjątkiem były odwołania do poezji Gawińskiego w pracach Piszczykowskiego (1977), Kuchowicza (1992), Bystronia (1994).
} 
rze klasycznej. Afirmacja wsi dokonana przez mieszkańca miasta jest świadectwem atrakcyjności ziemiańskiego modelu kultury².

Brak współczesnej krytycznej edycji poematu Miesięcy dwunastu z swoich okoliczności opisanie najprawdopodobniej jest spowodowany dość burzliwymi losami tekstu. Utwór został umieszczony przez autora w drugim tomie Helikonu, przechowywanym w Bibliotece Towarzystwa Warszawskiego Przyjaciół Nauk. Autograf ten zaginął podczas I wojny światowej (Chemperek, 2005, s. 9; Rot-Buga, 2013). Tekst Miesięcy dwunastu ... opisania zachował się jednak dzięki odpisowi sporządzonemu w 1810 roku na zlecenie Józefa Maksymiliana Ossolińskiego ${ }^{3}$. Pierwszą edycję poematu wydał Władysław Seredyński (Jana z Wielomowic, 1879, s. 226-236), oparta jest na założeniach obowiązujących w XIX wieku, zawiera błędy i nie podaje w przypisach wszystkich odmiennych redakcji autorskich, skopiowanych w przekazie z Ossolineum. Mimo zaginięcia autografu (poeta skrupulatnie wpisywał doń daty powstania swych utworów) istnieją przesłanki, na podstawie których można $\mathrm{z}$ dużym przybliżeniem określić czas ukończenia poematu. Skoro zawarty był on $\mathrm{w}$ drugim tomie Helikonu, zapewne powstał w późnym okresie twórczości poety - Gawiński spisywał swoje teksty w Helikonie zgodnie z chronologią ich powstawania (Chemperek, 2005, s. 18-19). Wzmianka zawarta przez autora w wierszu October. Październik o „niedawno ubłogosławionym” Janie Kantym pozwala określić ściślej ten czas. Beatyfikacja świętego miała miejsce 27 września 1680 roku, więc wiersze musiały powstać między końcem 1680 a 1683 rokiem (Chemperek, 2005, s. 337). Hieronim Juszyński w Dykcjonarzu poetów polskich podaje za zaginionym obecnie autografem, że zostały one ukończone w 1682 roku (Juszyński, 1820, s. 84-86).

Poemat składa się z dwunastu wierszy odpowiadających miesiącom, każdy z nich podzielony jest na sześć strof czterowersowych. Wiersze poświęcone poszczególnym miesiącom pojawiły się w literaturze polskiej już w XV wieku (Włodarski, 1997, s. 138-140). Nie są rzadkością w poezji barokowej, ale cykl im dedykowany - samoistna całość - był zdaniem Dariusza Chemperka novum (Chemperek, 2005, s. 337-338). Częściej przedstawiano prace polowe oraz zabawy stosownie do pór roku. Model ten został wykorzystany w wielu utworach, m.in. w Zabawach orackich Stanisława Słupskiego (Gruchała, Grzeszczuk, 1988, s. 190-202) oraz w Ekonomiji albo Porządku zabaw ziemiańskich Władysława Stanisława Jeżowskiego (Gruchała, Grzeszczuk, 1988, s. 245-252). Użycie przez Gawińskiego schematu dwunastoelementowego cyklu wynikać mogło z dwóch pobudek. Pod koniec życia poeta żywo interesował się literaturą popularną, między innymi dokonał uszlachetniającej XVI-wieczną stylistykę przeróbki sortilegium Stanisława Gąsiorka z Bochni (Chemperek, 2005, s. 323-326; Wojtowicz, 2010, s. 60; Kiliańczyk-Zięba, 2015, s. 37-41). Współpraca z drukarzem przy wydaniu zmodernizowanej edycji staropolskiej księgi wróżb - edytorskiego longsellera, była bez wątpienia intratnym przedsięwzięciem. Takie też mogły być powody powstania cyklu o miesiącach, który stałby się częścią kalendarza. Wysokonakładowe druki kalendarzy przynosiły spory zysk właścicielom oficyn i jest prawdopodobne, że przedsiębiorczy poeta chciał w tych zyskach partycypować. Na rzecz tej hipotezy świadczy

\footnotetext{
2 Nie jedyny to przykład tego rodzaju w literaturze staropolskiej, zob. przykładowo Efemeros, czyli Diariusz prywatny pisany w Zamościu w latach 1656-1672 Bazylego Rudomicza (Rudomicz, 2002).

3 Manuskrypt należy do zbiorów Biblioteki Akademii Nauk Ukrainy im. W. Stefanyka we Lwowie (zbiory d. Ossolineum), sygn. 280, k. $527 \mathrm{r}-538 \mathrm{v}$.
} 
fakt, że jeszcze w czasach saskich kalendarze były zaopatrywane w cykle miesięczne. Znane są co najmniej dwa takie utwory cykliczne z 1753 i z 1760 roku (12 miesięcy opisanie, 1975, s. 45-47, Obserwacje niektóre, 1975, s. 61-64). Drugim powodem powstania poematu o miesiącach mogła być znajomość Gawińskiego z Jakubem Kazimierzem Haurem, autorem Ekonomiki ziemiańskiej generalnej (1675), którą Jan z Wielomowic zaopatrzył w trzy łacińskie epigramaty (Chemperek, 2005, s. 76-79). Autor poczytnej encyklopedii ziemiańskiej zawarł w niej cykl Praktyka miesięczna gospodarstwa ziemiańskiego. Podobnie jak w późniejszym Miesięcy dwunastu... opisaniu podane są polskie i łacińskie nazwy miesięcy. Jednak tematyka obu tekstów jest różna: Haur przekazuje prozą praktyczną wiedzę, przydatną w zarządzaniu gospodarstwem, Gawiński zaś podziwia wiejską przyrodę z perspektywy mieszkańca miasta. Na przykład wiosenne nowalijki ogląda na targu miejskim, gdzie są sprzedawane przez wieśniaczki:

Wilaneczki z ogrodów, nowinki zielone

Poprzedawszy, stroją się w kształciki upstrzone.

(Maius. Maj, w. 15-16)

Poeta wyznacza czas roku poprzez rytm prac polowych oraz świąt kościelnych w poszczególnych miesiącach. Ze znawstwem pisze o żniwach, zbiorach i zabawach towarzyszących życiu wiejskiemu, zapewne odwołując się do wspomnień lat młodzieńczych lub do wizyt w podkrakowskich wsiach. Porusza też temat zwyczajów ludowych, na przykład w wierszu Iunius. Czerwiec pisze o próbie zniesienia obchodów sobótki (Mazurkiewicz, 1993, s. 128-129) i nawołuje do obrony tradycji:

Jan święty Chrzciciel przyszedł, więc palą sobótki,

A wkoło niej śpiewając, skaczą wiejskie młódki.

Nie znoście tych zwyczajów! Co nas z wieków doszło

I wiekiem się ustało, trzeba, by w wiek poszło.

(Iunius. Czerwiec, w. 21-24)

Gawiński ukazuje swój profil poety-klasycysty, percypując przyrodę przez pryzmat kultury chrześcijańskiej i mitologii, wątki dotyczące bogów czy nimf sprowadza do codziennych sytuacji, dzięki czemu osiąga efekt pogodnego humoru. Na przykład w zamarzniętych rzekach dostrzega „wodosiedza” Neptuna „Z swą zgrają” (Februarius. Luty, w. 10), w czasie ostatków „Bach [...] / Kogo bluszczem swym zetnie, dokoła się kręci” (Februarius. Luty. w. 23-24), zaś Mars „Z swoim warsztatem” (October. Październik, w. 22) schodzi z pola na czas zimy. Przedstawianie postaci mitologicznych oraz patronujący całemu cyklowi zamysł personifikacji świata przyrody pozwalają na subtelne i częste wprowadzanie wątków erotycznych, na przykład czerwcowy upał tłumaczy poeta żarem rozpalającym Febusa, który z nieboskłonu obserwuje kąpiącą się Dianę.

W poemacie można dostrzec nawiązania do dzieł innych pisarzy. Przywoływane są Sielanki Szymona Szymonowica, Pieśni Jana Kochanowskiego czy Bukoliki Wergiliusza. Subtelne reminiscencje z klasyków harmonizują z poetyckimi obserwacjami przyrody i obyczaju wiejskiego. Gawiński jawi się w Miesięcy dwunastu... opisaniu jako wrażliwy poeta, uważnie rejestrujący 
zmysłowe piękno natury nawet w jej zwykłej codzienności. Dostrzega wagę szczegółu, opisując chociażby mróz, wiosenne kwiaty czy jesienne mgły, ale też, dzięki licznym animizacjom, ujmuje przemiany w krajobrazie w sposób panoramiczny:

Rzeki oddech swój mają, ziemia ocucona

Wzgląda, a ciężar śnieżny z swego zrzuca łona.

Wiatr południ tchem ciepłym ostrą zimę siecze,

Ta uchodząc na szczudle, w swą się północ wlecze.

(Martius. Marzec, w. 5-8)

Jan z Wielomowic jawi się w poemacie jako barokowy klasycysta, powstałe niedługo przed śmiercią poety Miesięcy dwunastu... opisanie może być uważane za jego literacki testament:

Artystyczne novum, to [...] konsekwentna estetyzacja świata wynikająca z przyjęcia postawy klasycystycznej. Trop Kochanowskiego każe wystrzegać się poecie wszelkiej egzegeracji stylistycznej, akcentów osobistych, dążyć do formułowania prawd ogólnych, spójnej i harmonijnej wizji rzeczywistości. Nie rezygnuje wszakże Gawiński z barokowej stylistyki i próby przewartościowania renesansowego klasycyzmu. Zmysłowe piękno sielskiej przyrody, oddane za pomocą środków brzmieniowych, tropów, sentencji, ma ideologiczną sankcję w hedonizmie. Imperatyw przyjemności i rozkoszy kieruje poczynaniami bohatera, zapraszając do uczt i korzystania, wzorem natury, z uciech miłości. (Chemperek, 2005, s. 346-347)

Cykl przedstawia sugestywnie piękno przyrody i życia w zgodzie z nią na przestrzeni całego roku. Opisanie każdego miesiąca z osobna pozwala dostrzec nawet najmniejszą zmianę natury i wpisać w nią ludzką egzystencję. Gawiński w poemacie zawarł pochwałę codziennego i szczęśliwego życia, które dostępne jest dla każdego człowieka.

\section{Opis źródła}

Podstawą transkrypcji był odpis autografu wykonany na zlecenie Józefa Maksymiliana Ossolińskiego w 1810 roku, zachowany w Bibliotece Akademii Nauk Ukrainy im. W. Stefanyka we Lwowie (dawne Ossolineum), sygn. 280, k. 527r-538v.

W kopii z Ossolineum zaburzona została kolejność miesięcy, September. Wrzesień i October. Październik znajdują się między wierszami Aprilis. Kwiecień a Maius. Maj. Tekst jest również niekompletny: brakuje ostatniego wyrazu w części December. Grudzień, w. 12, oraz za oryginałem brak w. 1320, co odnotował kopista: „W ostatnim miesiącu Grudniu opuszczone strofy 4. i 5.” (k. 538v). Kopia uwzględnia również alternatywne wersje niektórych strof lub wersów. Warianty zostały oznakowane w tekście skrótem „vel” (zazwyczaj występującym w odpisie). Ponieważ podstawą edycji jest XIX-wieczny odpis i nie sposób określić ostatecznej woli autora, pozostawiono warianty poszczególnych wersów czy zwrotek w przypadkach, gdy ich treść jest całkowicie odmienna (zob. Aparat krytyczny)4.

4 Decyzja ta może kłócić się z paradygmatem edycji krytycznej za sprawą równorzędnego potraktowania dwóch wersji tekstu (przyp. red.). 
Ta decyzja ma uzasadnienie w specyfice metody twórczej, warsztatu poetyckiego autora, który w swej epigramatyce bardzo często i kreatywnie stosował praktykę wariacji, na przykład stworzył dwudziestodwuelementowy zbiór fraszek Na rzekę lodem spięta (Chemperek, 2005, s. 211-212, 252-256). Pozostałe warianty, w których autor powtarza tę samą myśl, przeniesiono do aparatu krytycznego.

\section{Znaki edytorskie przyjęte w edycji}

W edycji przyjęto następujące znaki edytorskie:

$<>-$ nawiasy kątowe w tekście sygnalizują koniekturę wydawcy

$<\ldots>$ - nawiasy kątowe $\mathrm{z}$ wielokropkiem sygnalizują lukę w tekście przekazu

\section{Zasady transkrypcji}

W transkrypcji tekstów uwspółcześniono interpunkcję oraz zapis wielkich i małych liter.

Zmodernizowano pisownię łączną i rozdzielną (np. wkwiateczki $\rightarrow$ w kwiateczki, zogrodów

$\rightarrow z$ ogrodów, do koła $\rightarrow$ dokoła). Pozostawiono pisownię łączną w wyrażeniach przysłówkowych: potym.

Uwspółcześniono pisownię samogłosek $i, j, y$ (np. iedne $\rightarrow$ jedne, nastaie $\rightarrow$ nastaje, konop$n e y \rightarrow$ konopnej, Maciey $\rightarrow$ Maciej). W wyrazach pochodzenia obcego, gdzie $-i-$, $-y$ - pełnią funkcję grup -ij-, -yj-, wprowadzono dodatkowe -j- (np. lilie $\rightarrow$ lilije, wioli $\rightarrow$ wijoli, maniery $\rightarrow$ manijery). Pozostawiono e, o pochylone w pozycji rymowej (słodkiéj / jagodki, przybywa / nawiéwa, roży / mnoży).

Uwspółcześniono pisownię o, ó, u (np. poznieyszy $\rightarrow$ późniejszy, moi $\rightarrow$ mój, mroz $\rightarrow$ mróz, chor $\rightarrow$ chór, rożek $\rightarrow$ różek).

Zmodernizowano pisownię samogłosek nosowych (np. benbenku $\rightarrow$ bębenku), nie uwzględniając rozłożenia nosówki (kolęnd $\rightarrow$ kolęd).

Zastosowano współczesne zasady pisowni głosek dźwięcznych i bezdźwięcznych (np. wieść $\rightarrow$ wieźć, bydz $\rightarrow$ być, ztąd $\rightarrow$ stąd). Zgodnie ze współczesnymi zasadami transkrybowano spółgłoski $z / \dot{z} / \check{z}$ (np. druzyna $\rightarrow$ drużyna, az $\rightarrow a \dot{z}$, poznieyszy $\rightarrow$ późniejszy), $c / c ́ c c z($ depc $\rightarrow$ depcz, uszczknac $\rightarrow$ uszczknąć, patrzec $\rightarrow$ patrzeć $)$ oraz s / ś / ś (szczęsliwy $\rightarrow$ szczęśliwy, swiat $\rightarrow$ świat, snieg $\rightarrow$ śnieg, srony $\rightarrow$ szrony). Zachowano wahania w wyrazach władarzem, włodarstwo. Znaki diakrytyczne zapisywano według współczesnej normy (np. konską $\rightarrow$ końską, uszczknąc $\rightarrow$ uszczknąć, sliczne $\rightarrow$ śliczne). Zachowano podwojenie spółgłoski (Dyjanna).

Zostawiono jednorazowo formę $w$ czesiech ('w czasach') w pozycji rymowej ( $w$ czesiech / w lesiech).

W obrębie grup spółgłoskowych zachowano połączenie źrz-, przy czym jako źrze- transkrybowano pojedyncze zapisy zrze- (np. zrzedlnic $\rightarrow$ źrzedlnic, zrzenice $\rightarrow$ źrzenice).

Pozostawiono końcówki -em, -emi w narzędniku l. poj. i l. mn. oraz w miejscowniku l. poj. w odmianie przymiotnika i zaimka (np. temi, wszem).

Zmodernizowano pisownię wyrazów pochodzenia obcego oraz spolonizowanych nazw własnych (np. Phenix $\rightarrow$ Feniks, Phoeb $\rightarrow$ Feb, Nimpha $\rightarrow$ nimfa, Aquilonow $\rightarrow$ akwilonów). 


\section{Aparat krytyczny}

\section{Februarius. Luty}

w. 12

$w$ poly - poprawka wydawcy; $i w$ poły

Alternatywny wariant wersu:

$Z$ trzaskiem lód wrzeszczy i dłużej rozwala.

\section{Martius. Marzec}

w. 3 bo gdy marzec płacze - poprawka wydawcy; bo gdy: bo gdy Marzec płacze - rkps.

w. 19 według edyktu - poprawka wydawcy; według dawnego edyktu - rkps.

\section{Aprilis. Kwiecień}

Ze względu na treść zamieniono miejscami strofę 5. i strofę 2.

w. 1-4 Wariant zwrotki:

Obumarła Helice słońce dobrze grzeje,

Swiat rozkwita i w nowe kasze się nadzieje,

Drzewo w listki się kryje, a od srebrnej rosy

Ziemia wilga rozplata swoje śliczne włosy.

w. 15-16 Wariantowa wersja:

Wrona za pługiem chodzac, zbiera też robaczki,

A z głodu temi posila gardziel swój ślimaczki.

w. 17-20 Alternatywna (wariantowa) wersja wersów:

Ziemia zielona barwe tu już wdziewa na się,

$W$ cerze co dzień weselej odmłodniać zdaje się,

$Z$ podciętych brzóz sok płynie, co go satyr chlipie,

Potem $w$ tańce, gdy mu Pan $w$ różek swój zaskrzypie.

w. 20 Wariant wersu:

Potem $w$ tańce, gdy mu Pan $w$ drewna dwie zaskrzypie.

\section{Maius. Maj}

w. $14 \quad Z$ nich dziedziczki hyblejskie zdobycz słodka biera - poprawka wydawcy; Słodka zdobycz z nich dziedziczki hyblejskie zdobycz słodkg biera - rkps.

w. 22 Wariant wersu: Brzemię słodkiego miodu z rosa pada.

\section{Iunius. Czerwiec}

w. 5 Dyjanna - poprawka wydawcy; Byanna - rkps.

\section{August. Sierpień}

w. $6 \quad$ bici<u> - poprawka wydawcy; bicie - rkps.

w. $24 \quad p<r z y>-$ poprawka wydawcy; po - rkps.

\section{September. Wrzesień}

w. $12<t>a k$ - poprawka wydawcy; jak - rkps. 
w. $17 \quad z$ ostawu<j>-poprawka wydawcy; zastawu - rkps.

w. 19 do spichlerza - poprawka wydawcy; do spiżarnie, spichlerza - rkps.

w. 23b-24b Alternatywna (wariantowa) wersja:

Acz bodaj nie w tej doby $z$ niebios jest zepchnięta

Przez wodza archaniołów w głąb orda przeklęta.

\section{November. Listopad}

w. $4 \quad$ Czas $m<i e n>i$ - poprawka wydawcy; czas memi - rkps.

w. 7-8 Wariantowa wersja:

Podsyć myśl winny muszec pszenneli do woli

I harc zwiedź z kumem, z kuma przy wiejskiej wijoli.

\section{December. Grudzień}

w. 12 ogień < rozpalają> - poprawka wydawcy; ogień - rkps. 


\section{Jan Gawiński}

\section{Miesięcy dwunastu z swoich okoliczności opisanie}

\section{Ianuarius. Styczeń}

Czemu dwojej mię twarzy być znają osobą?

Bo jedne rzeczy widzę przed, drugie za sobą.

Szczęśliwy, co z przeszłych lat na przyszłe miarkuje,

A każdą rzecz, jak wyńść ma, z końca upatruje.

5 Ja władarzem przezornym całego się roku

Być poczuwam, na moim czas późniejszy oku.

Ja i królów do Pana nad pany przyjmuję

I na wszytek świat gody cudowne sprawuję.

W domu mym maluchnego, lecz co wielki rządzi

10 Świat, Pana mam, co przeszły i przyszły wiek sądzi.

Więc od tego początek, nie od mojej części

Bierzcie Pana, a On wam w cały rok poszczęści.

Z dwunastum braci pierwszy i takim się szczycę

Pierszeństwem, wzgląd w przyszłe mam i przeszłe księżyce,

15 Ja i zimę w mym czasie najgruntowniej stalę,

A śnieg hojno roztrząsam spod powietrznej sale.

Nowy Rok, Nowe Lato pod łagodnym zwiskiem

Zaczynam, z całym całej zimy stanowiskiem,

W mój czas droga anielska, gdy kto z nimfą wdzięczną

20 Śliskim płozem pojeżdża pod łunę miesięczną.

Zima, gęstymi dmami mroźnych akwilonów

Gnana, od zmarzłych Helic spod Siedmitryjonu

Państwo swe rozpościera: śnieg, mróz, białe szrony -

Hurmem na świat zapuszcza te to swe zagony.

\section{Februarius. Luty}

Luty ziemię lutuje: kędy wody stały,

Teraz się w krzyształowe mosty zobracały.

Tłuszcza rybna dziedziców w pieczary, pode pnie

Wchodzi, a płoć biedactwo w szkło lodowe krzepnie. 
5 Śnieg kupami się wali, wiatry dmą z północy, Mróz się iskrzy po świecie, pełen swojej mocy. Wszem kosmaczom u wąsów i konopnej brody

Wiszą zmarzłe gałgany i chrzęszczące lody.

Miąższy lód wodę w rzekach ku dnowi aż ściska,

10 Neptun na dnie z swą zgrają szczupłe ma siedliska,

Więc gdy $\mathrm{z}$ boku jednego $\mathrm{w}$ drugi się przewala

Ten wodosiedź, lód drużdże, w poły go rozwala.

Świat osiwiał, pod kupą śniegu drzewa mdleją,

Po dachach gonty trzeszczą, dmy śnieżyste wieją.

15 Pal w izbie, grzej się winem lub pszennym likworem,

Jako nasi ojcowie tym czynili torem.

Chuchaj i depcz nogami, ręce kładź w zanadrze,

Niewiele się zagrzejesz, gdyć się suknia nadrze.

Dobądź lisiej lub rysiej, albo skopiej skóry,

20 Ciepło zawsze przyjaciel do ludzkiej natury.

Ziemia zimą stężała, ale święty Maciéj

Strofuje ją, że w jego dób moc swoję traci.

O tychże dniach szalenie Bach zapusty święci,

Kogo bluszczem swym zatnie, dokoła się kręci.

\section{Martius. Marzec}

Zimy marzec dokończa i wiosny początkiem,

Marzec starych tnie kosą, młodszych podczas prątkiem.

I ziemie nie przepuszcza, bo gdy marzec płacze,

Wedle nowej powieści rzadko zje kołacze.

5 Rzeki oddech swój mają, ziemia ocucona

Wzgląda a ciężar śnieżny z swego zrzuca łona.

Wiatr południ tchem ciepłym ostrą zimę siecze,

Ta uchodząc na szczudle, w swą się północ wlecze.

Zima na krach lodowych w pełnym płynie brzegu,

10 Którą wiatr południowy wśród połyka biegu.

Neptun zmarzły z sitowia wąs i trzcinną brodę

$\mathrm{Z}$ zmarzlin strząsa słoneczka w cieplejszą pogodę. 
W marcu zima truchleje, ty przecie pal w izbie,

Nie daj przez próg wstępować zimnej jeszcze ciżbie.

15 I ty, nestorze letni, ciepło się miej, by cię

W marcowe dni śmierć w swoim nie zabrała mycie.

W końcu marca Zima się swym rusza obozem

W kraj północny i nie tak swym straszna przegrozem.

Pod niebem żuraw krzyczy, a według edyktu

20 Kaczka jajko świętemu znieść ma Benedyktu.

Zima swą ostrość składa: pola, rzeki, lasy,

W których były, rwą mroźne niewolstwa tarasy.

Pal ty przecie i w izbie siedź ciepłej, bo ziemna

Wilgoć szkodzi i człeku dziś jest nieprzyjemna.

\section{Aprilis. Kwiecień}

Już weselszą ku niebu ziemia wzgląda twarzą,

Pierwocinne kwiateczki po polach się żarzą,

Wsze stworzenie niezwykłą radość swą pojmuje:

Pan, zwycięzca zwycięzców, z śmierci tryumfuje.

5 Ziemia $\mathrm{z}$ gnustwa powstaje, pozbywszy siwizny,

Mchem zielonym nakrywa wszelkie swe golizny,

Poseł ptastw, skowroneczek, włodarstwo zaczyna,

Pastereczkę $\mathrm{z}$ oraczem $\mathrm{w}$ pole napomina.

Z lasów, gór i potoków gęste strugi płyną,

10 Z większą rzek, rzeczek innych ku Wiśle drużyną.

„Rubakier!” - styrnik woła, Gdańsk tej żyznej flocie

Radując się, gotuje dar za dar we złocie.

Oracz ziemię rznie pługiem i wielkiej macierzy

Płodu Cererzynego na oddanie wierzy.

15 Skowronek nad nim wisząc swe rozczyna gorgi,

A Tytyr trzodę żenie w ugorowe morgi.

W puszczy z brzóz spod żądanej ostrą stalą plagi

Płyną smaku słodkiego samorodne lagi.

Ten chlipią satyrowie, a podniósłszy nóżek,

20 W tany potym, a Pan im w swój przygrywa różek. 
Panny i wsze matrony, wasz dozór nastaje:

Różane ogródeczki, ogród - wasze raje.

Siejcie, sadźcie kwiateczki i różne jarzynki,

Byście co kłaść na czoło mieli i do skrzynki.

\section{Maius. Maj}

Piękna w szacie majowej Flora się przechodzi,

Co jej ziemia z róż wonnych, co i z lilij rodzi,

Z niej wzór biorąc ogrody i różańce śliczne,

$\mathrm{Na}$ jej przyjście w kwiateczki stroją się rozliczne.

5 Świat odmłodniał, natura wszelki płód wydaje,

Maj ludzkim dzisiaj oczom ziemskie stawia raje.

Kwitną drzewa, ogrody, a pod krzakiem roży

Wenus z pięknym Adonem swe pieszczoty mnoży.

Słońce, Wenus, promieniem tocząc na świat lubem,

10 Wsze stworzenie jednoczy przyrodzonym ślubem,

Perłowa z niebieskich się źrzedlnic rosa leje,

Że z niej ziemia wszelakim płodem brzemienieje.

Sady kwitną rumianą i w śnieg bielszą cerą,

Z nich dziedziczki hyblejskie zdobycz słodką bierą,

15 Wilaneczki z ogrodów nowinki zielone

Poprzedawszy, stroją się w kształciki upstrzone.

Pola, sady, ogrody, łąki zielenieją,

Gospodarz na to patrząc, cieszy się nadzieją:

Boże, tu cuda Twoje, tu Twe wielkie dziwy,

Wszytko rodzisz i dajesz, Ojcze dobrotliwy.

Nie tak w drogiej są cenie perły z oceana,

Jako rosy spod niebios opuszczone $\mathrm{z}$ rana,

Po nich wszelkie się zboża, kwiatki z ziemi ronią,

Zapach i wdzięczną na świat rozpuszczając wonią.

\section{Iunius. Czerwiec}

Chrzciciel święty Jan przyszedł, tu nam chrzci nowiny,

Które ziemia w użytek dała pierwociny,

Stal ostra łąki goli, polny kwiatek mdleje.

Że i jemu toż będzie, co się trawie dzieje. 
5 Tu się Dyjanna kąpie i swe śliczne członki Pod przezroczyste tuli wód pięknych zasłonki,

Nie mażci Akteona, ale się sam pali,

Po niebieskiej Feb tocząc wóz ognisty sali.

Wzwodzą swoje ptaszynki, drobiażdżek maluty,

10 Na świat ptasze maciorki, piórkami niezsuty,

A drugie się gotują. Sam Feniks jedyny,

Co w wiek aż swe w słonecznym ma ołtarzu chrzciny.

W brzaski Lucyferowe i późne Hespery

Słyszeć dźwięk ptaszych kapel różnej manijery:

15 Tu stąd wdzięczny napiewa chór, a ówdzie gorgi

Skrzeczą czarnych ptactw z ptakiem złotookiej forgi.

Czerwiec łąk odprawuje pierwsze postrzyżyny,

A ogród i sad swemi chlubi się nowiny:

Nie tylko złoto w cenie, podczas i malinka

20 Zacz jest, którą przyniesie nadobna Halinka.

Jan święty Chrzciciel przyszedł, więc palą sobótki, A wkoło niej śpiewając skaczą wiejskie młódki.

Nie znoście tych zwyczajów, co nas z wieków doszło

I wiekiem się ustało, trzeba, by w wiek poszło.

\section{Iulius. Lipiec}

Żniwo idzie i żeńców idzie też niemało,

W Boży czas zacznij sierpem, gdzie zboże dostało.

Oluchna w kupie żeńców pięknie przyśpiewuje,

Przy muzyce robota spieszniej postępuje.

5 Słońce piecze. Po górach pastereczka basie,

Trzódkę swoją kochaną, przy leszczynie pasie.

Tytyr, podle niej siedząc, czegoś u niej skumli,

Przygrywając jej luto na brzęczącej drumli.

Zboże pory dostawa. Wójt starą kordelę

10 Na sierp każe przerabiać w gorącym popiele.

Idą żeńcy, a plenny, dostawszy swej miarki,

Kłos się chyli i sierpom swe poddaje karki. 
Gruszki pierwsze, wisienki, pachniące równianki,

Te dostatki przynoszą do miasta kmiecianki.

15 Sam gospodarz dostałe siecze siana, a te

Zwozi pilno i kładzie w bróg końską sałatę.

Od słonecznych upałów pod bukowe cienie W las swe trzody Dameta z Likorydą żenie,

Tam młodzież z gniazd ptaszęcych wybrawszy, bankiety

20 Sobie stroją, a potym w las idą na wety.

Panna $\mathrm{z}$ wdzięcznym paniczem $\mathrm{z}$ upału dwojego Idą w sad pod cień drzewa labiryntowego.

Tam po ucztach fruktowych, po rozmowie słodkiéj,

Swej natenczas mu uszczknąć pozwala jagodki.

\section{August. Sierpień}

Kopy gęste po polach świecą się jak gwiazdy,

Pan wesól, że swej pewien jest do Gdańska jazdy.

A chłopek też, na bakier giermak przekrzywiwszy,

Smyka fury do miasta i śpiewa podpiwszy:

5 „Słoneczko, śliczne oko, dnia oko pięknego,

Znieś gniew i zapał w bici<u> starosty naszego.

Nie wie, jak nam przy sierpie trójpot idzie z czoła,

A on przecie: »Pożynaj« bez przestanku woła.”

Pod kopami zbóż różnych aż pola stękają,

10 Więc do gumien przestronych z pól się przenaszają.

Kmiotek wesół po pracy, a na to swe żniwo

Przyjechawszy do miasta, siecze dobrze piwo.

Chyba w święto przyjeżdżaj, alboli w niedzielę,

Jam dziś gospodarz w polu, lecz w domu niewiele.

15 Niesmaczny gość w robotne chwile, a tak każdy,

By praw sobie i komu był, niech niecha jazdy.

Teraz się w winohradach winne smażą grona

I na jabłko barwica wychodzi czerwona.

Rwij je, grzeczny młodzianie, a pisz słowa na niem:

20 „Piękniejszej ten dar służy, co mym jest kochaniem”. 
Z pól w gumna jedzie Ceres. Pszennego towaru

Dość, pan wesół, że będzie miał z czym do browaru.

Żeńcy, żniwo skończywszy, panu wieniec wiją,

A skacząc po bębenku, z beczki piwo piją.

\section{September. Wrzesień}

Pożąłeś? Siejże znowu. Dobry handel z niebem,

Kiedyć ziarno sowitym nagradza się chlebem,

A czujna gospodyni, wiedząc jako siła

Zjada rok, myśli, jakoby mu się złożyła.

5 Sforz psy, da charci w pole, nieboraku kocie,

Żeś się dobrze uchował, gra tu idzie o cię,

Psi twój kożuch targają. Aleć i przepiórka

Krogulcowi swe daje testamentem piórka.

Jabłuszeczko czerwone i gruszka żółtawa,

10 Że dojrzałe, łacno się już urywać dawa.

Panie, jedź, dojrzyj siewu lub poślij wiernego,

Jeśli gdzie, $<\mathrm{t}>$ ak tu pole chce oka pańskiego.

Dzień krótszy, a noc głębsza spośród Oceana

Północnego przychodzi, ćmami mroków gnana,

15 Więc co robót dzień nie zmógł, przy świetle ostatka

Twoja niechaj dokańcza z wieczora czeladka.

Coć z sierpa kłoski spadły, zostawu $<j>$ na roli (Boskie prawo to chce mieć dla uboższej doli), A przecię siej. Włożysz to jakby do spichlerza,

20 Co tej matce twa ręka do ziemi powierza.

Rajskie jabłka w purpurach i winniczne purty

Idą w miasta, a drugie za zamczyste furty,

Panom w smak osobliwy i stołom okrasy,

Co obok z cukrowymi ścierają się masy.

vel

21b Wtenczas Marsowym tańcem dochodzą potrzeby,

Że jednym laury wstają, a drugim pogrzeby,

Acz bodaj nie w tej doby Lucyper przeklęty

Pchnion z niebios $\mathrm{w}$ dolny taras z swemi adherenty. 


\section{October. Październik}

Jeden skarb z polaś zebrał, drugiś depozytem

Ziemi dał, że go z płatem odbierzesz sowitem,

Więc po pracach tych sobie wytchni i biesiady

Zażyj, nawiedzając swe pobliższe sąsiady.

5 Cyt okropne świat trzyma. W polu ani w lesiech

Żadnej ptaszej muzyki w tych nie słychać czesiech,

Oprócz, co po kiermasiech, które gęste święcą,

W dudy dmą, albo wrzeszczą, gdy się mózgi męcą.

Już ostatnie bogactwa z ogrodów, jarzyny

10 Przenoszą się na zimę do ziemnej jaskini.

Lilie, krzaczki kwiatów, rozmaryny w lochy

Idą mieszkać, bojąc się zimy - złej macochy.

Jesienna pora przyszła, w którą nam przybywa

Chorób ćma, co ich Auster silną dmą nawiéwa,

Co po przeszłych niedawno oczupasach świata

Weselszego ozdoby z drzew i sadów zmiata.

Ja czczę nową Jutrzenkę, klejnot drogiej perły,

I męża nauk świętych z królewskimi berły,

Dwóch Sarmatów niedawno ubłogosławionych:

20 Kostkę z Kantym w naukach w Bogu zjednoczonych.

Schodź z pola z swym warsztatem Marsie, bo już ziębi,

Sam cię czas płaczorody wszech niewczasów zgnębi.

Saturn trzęsie Plejadmi z mokrym Oryjonem,

Że ten i te słoty dżdże pełnym leją tonem.

\section{November. Listopad}

O nietrwałe uciechy i piękności zwierzchnie,

Równe dniowi krótkiemu, co wstaje i mierzknie!

Niedawnoście cieszyły świat, ludzkie źrzenice,

A zginiecie! Czas $m<i e n>i$ wesela $w$ tęsknice.

5 Zimna, chaje, dmą w okna słoty, niepogody,

Ty w izbie ciepłej wtedy zażyj swej wygody.

Podsyć myśl, z przyjacielem uciesz się do woli,

Jestli kuma? Więc harc zwiedź przy wiejskiej wijoli. 
Wszyscy święci są hojni, kolęd wiodą zgrają,

10 Od nich dobry początek, sami ją wprzód dają.

Drudzy za ich przykładem, święty Marcin zwłaszcza,

Co ubogim rznąć z siebie nie żałował płaszcza.

Przebóg, co za głos żalu i wnętrznej ciężkości

Uszu naszych dochodzi z ziemi głębokości?

15 Zmiłujcie się nad nami, wy przynajmniej, w ciele

Co żyjecie, nad duszami, nasi przyjaciele.

Gotuj na stół tłustą gęś, zwróżym z niej o zimie, Mokreli, albo mroźne rządy swe obejmie,

A nie żałuj naczynia dobrej myśli - wina,

20 Tego żąda po tobie twa wierna drużyna.

Ziemia wilgoć wyziewa, a ćmy się szarawe

Rozciągają po świecie, naturom nieprawe.

Człek truchleje, że pod tym świat mglistym obłokiem, Że i w słońcu zabrania jasnym patrzeć okiem.

\section{December. Grudzień}

W mym się cuda w wiek wieków domie wielkie dzieją,

Z skały oliwa, z dębów balsamy się leją,

Z zwiędłych krzaków lilije. To wszystko przechodzi,

Gdy czysta Panna Boga, córka Ojca rodzi.

5 Ja rok kończę i zimę prawdziwą przywodzę,

I najmniejszy dzień, ale noc największą rodzę.

Lecz i światłość nad wszelką światłość u mnie wschodzi:

Bogarodzica Panna wieczne światło rodzi.

Zima do izb zagląda i do drzwi się wciska,

10 Tam chcąc mieszkać, gdzie rzadko w piecu ogień błyska,

Lecz domowy z Wulkanem lar jej odpór dają,

Gdy w piecu nieustanny ogień <rozpalają $>$.

$<\ldots>$

Bogu cześć wieczną dawaj, żeć do końca roku

Dał przyjść, a w wiecznym zbronił zapadnąć ci mroku.

A jakoć dał szczęśliwie ten rok wieść kończący,

Niechaj ci da takowy wiek następujący. 


\section{Komentarz edytorski}

\section{Ianuarius. Styczeń}

Tytuł Ianuarius - miesiąc Janusa (zob. niżej).

w. $1 d$ wojej... twarzy - określenie odnosi się do jednego z najstarszych italskich bóstw - Janusa, patrona wszelkiego porządku. Przedstawiany jest on z dwoma przeciwlegle zwróconymi twarzami, jedna z nich patrzy w przeszłość, druga w przyszłość.

w. 3 miarkuje - domyśla się na podstawie czegoś, dedukuje.

w. $4 \quad$ A każda rzecz, jak wyńść ma, z końca upatruje - sens: w tym, co czynisz, bierz pod uwagę skutek działania, zwrot przysłowiowy (zob. Krzyżanowski, 1969-1972: „koniec” 2).

wyńść - wyjść

w. 5 władarzem przezornym - ostrożnym, czujnym gospodarzem.

w. 6 na moim czas późniejszy oku - sens: sprawuję władzę (kontrolę) nad czasem w całym roku.

w. 7 królów do Pana nad pany przyjmuje - mowa o święcie Epifanii, zwanym Trzech Króli, obchodzonym 6 stycznia.

w. 8 gody - karnawał, zapusty, okres od Bożego Narodzenia do Trzech Króli; czas śpiewów, radości, wesela.

gody... sprawuję - świętuję karnawał (zapusty).

w. 9-10 maluchnego, lecz co wielki rządzi / Świat - mowa o nowonarodzonym Jezusie.

w. 14 przyszłe... i przeszłe księżyce - przyszłe i przeszłe miesiące; odwołanie do dawnego podziału roku na miesiące księżycowe, według kalendarza synodycznego (babilońskiego), który był oparty na fazach księżyca. Miesiąc księżycowy dzieli się na 29 dni, 12 godzin, 44 minuty i 3 1/3 sekundy (Zajdler, 1977, s. 11).

w. 15 zimę... stalę - utwierdzam zimę, sprawiam, że jest w pełnej okazałości.

w. 16 spod powietrznej sale - metaforycznie: spod nieba.

w. 17 Nowe Lato - okres kolędowania, składania życzeń i podarków, także w formie pieśni czy dowcipnych wierszy.

w. 17-18 pod łagodnym zwiskiem / Zaczynam - sens: zaczynam pod łagodną nazwą (zwiskiem).

w. $18 z$ całym całej zimy stanowiskiem - sens: $\mathrm{z}$ tym, co zima niesie ze sobą.

w. 19 droga anielska - miła, przyjemna, także biała (ośnieżona); dalej mowa o kuligu.

w. 20 pod łunę miesięczna - w światło księżyca.

w. 21 akwilonów - zimnych wiatrów, od Akwilona (gr. Boreasz) - mitologicznego boga wiatru północnego, przynoszącego chłód.

w. 22 od... Helic - od gwiazdozbioru Wielki Wóz (Wielka Niedźwiedzica); mityczna Helice była nimfą, jedną z dwóch piastunek Zeusa, którą ten $\mathrm{z}$ wdzięczności przemienił w konstelację Wielkiej Niedźwiedzicy.

Siedmitryjonu - (łac. Septemtriones) siedem gwiazd tworzących konstelację Wielkiego Wozu. 
w. 24 Hurmem - gromadą, grupą.

zagony - oddziały, zastępy wojska, tu: mowa o śnieżycy.

\section{Februarius. Luty}

w. 1 lutuje - czyni twardą.

w. 3-4 Tłuszcza rybna dziedziców w pieczary, pode pnie / Wchodzi - inwersja: stado narybku, potomstwa (tłuszcza rybna) dużych ryb (dziedziców) chroni się w niezamarzające zakątki zbiorników wodnych.

w. $4 \quad$ w szkło lodowe krzepnie - zamarza.

w. $7 \quad k o s m a c z o m-$ osobom o bujnym owłosieniu, zaroście.

konopnej brody - płowej, niezadbanej, rosnącej naturalnie brody (podobnej do gałganu konopnego).

w. 9 Miąższy - gruby, masywny, ciężki.

w. 10 Neptun - (gr. Posejdon) tu jako bóg wód słodkich.

z swa zgraja - żartobliwie o dworze Neptuna; do orszaku jego oraz żony Salacji (gr. Amfitryty) należeli: ich syn Tryton, córka Roda, bożkowie morscy (m.in. Proteus), nimfy morskie nereidy (okeanidy) i trytony.

w. 12 wodosiedź - omowne określenie Neptuna. drużdze - druzgocze.

w. $14 d m y$ - wichry, zawieje.

w. 15 pszennym likworem - peryfrastycznie: wódką, nalewką.

w. 19 Mowa o różnych adresatach utworu: średniozamożnej szlachcie, która chodziła w płaszczach (szubach) podbitych lisim futrem, magnaterii czy bogatej szlachcie, która wykorzystywała na okrycia drogie skóry rysie, oraz szlachcie szaraczkowej, plebejuszach, którzy zimą chodzili w kożuchach.

w. 21 święty Maciéj - dzień św. Macieja, przypadający na 24 lutego, jest zwyczajową granicą zapustów (karnawału) zwanych ostatkami.

w. $22 w$ jego dób moc swoję traci - po 24. lutego zima traci swoją siłę.

w. 23-24 Bach zapusty święci, / Kogo bluszczem swym zatnie - Bachus (gr. Dionizos) - bóg winnej latorośli, wina, plonów i płodności. Na jego cześć urządzano bachanalia święta wina, tańca i zabawy. Atrybutami Bachusa były tyrs - drewniana laska zakończona szyszką i owinięta bluszczem - oraz winna latorośl.

w. 24 bluszczem swym zatnie, dokoła się kręci - smagnie winoroślą, tj. spije winem i biesiadnik tańczy.

\section{Martius. Marzec}

Tytuł Martius - nazwa pochodzi od mitologicznego Marsa, rzymskiego boga wojny. Poświęcony był mu miesiąc marzec, bo wtedy wznawiano przerwane na czas zimy wojny.

w. 2 Marzec starych tnie kosa - marzec uważany był za miesiąc częstych zgonów ludzi starych; nawiązanie do przysłowia: „W marce mrą starce” (Krzyżanowski, 19691972: „marzec” 6). 
podczas - niekiedy, czasem.

prątkiem - kolcem, szpilką, rózgą; mowa o lżejszych chorobach, którymi marzec... tnie... młodszych.

w. 3-4 gdy marzec płacze, / ... rzadko zje kołacze - sens: gdy w marcu pada, będzie nieurodzaj; nawiązanie do przysłowia: „Kiedy w marcu deszczu wiele - nieurodzaj zboża ściele” (Krzyżanowski, 1970, 1969-1972: „marzec” 17).

powieści - przysłowia, powiedzenia.

kołacze - ciasta weselne, obrzędowe, synonim obfitości, bogactwa.

w. 5 Rzeki oddech swój maja - mowa o odwilży, roztopieniu się lodu.

w. 5-6 ziemia ocucona / Wzgląda - wygląda, w domyśle - spogląda czarną powierzchnią spomiędzy płatów śniegu.

w. 7 południ-południowy.

w. 8 uchodząc na szczudle - kuśtykając, idąc.

w. 9-10 Sens: szybki wiatr południowy roztapia lodowe kry płynące po wezbranej rzece.

w. 11 Neptun - zob. objaśnienie do Luty w. 10.

w. 11-12 Neptun zmarzły... / strząsa słoneczka w cieplejsza pogodę - anakolut, mowa o miganiu refleksów słońca, błyskach na szadzi osadzonej na sitowiu i trzcinach.

w. 15 nestorze letni - starcze, tj. mający wiele lat. Nawiązanie do Nestora, jednego z bohaterów Iliady, najstarszego wodza greckiego walczącego w wojnie trojańskiej.

w. 16 śmierć w swoim nie zabrała mycie - śmierć jest poborcą, który pobiera opłatę, cło życie.

w. 17 Zima się swym rusza obozem - personifikacja zimy jako wodza, hetmana, który przemieszcza się ze swym wojskiem, tu: uchodzi.

w. 18 przegrozem - pogróżką, groźbą.

w. 19 żuraw krzyczy - symbol wiosny, przenikliwe odgłosy (klangor) żurawi są znakiem wiosennego powrotu ptaków.

według edyktu - według obwieszczenia wydanego przez władcę, tu: zgodnie z obyczajem.

w. 20 Kaczka jajko świętemu znieść ma Benedyktu - imieniny Benedykta przypadają na 11 marca. Kaczki zaczynają się nieść wraz z początkiem wiosny. Zob. przysłowie: „Na święty Benedykt, kaczka jaje myk” (Krzyżanowski, 1969-1972: „Benedykt św." 3).

w. 22 tarasy - tu metonimicznie: więzy, pęta.

\section{Aprilis. Kwiecień}

w. $1 \quad$ wzgląda - wygląda, patrzy.

w. 2 Pierwocinne kwiateczki po polach się żarza - pierwsze (wiosenne) kwiatki odznaczają się na polach z racji intensywności koloru. Prawdopodobnie mowa o kaczeńcach.

w. $4 z$ śmierci tryumfuje - mowa o święcie Wielkanocy.

w. $5 z$ gnustwa $-\mathrm{z}$ lenistwa, $\mathrm{z}$ uśpienia, mowa o wcześniejszym braku wegetacji.

w. 7 włodarstwo - gospodarzenie, panowanie. 
w. 7-8 Por. (96) Oracz (Gawiński, 2007, s. 117):

Dzień dobry, skowroneczku, już ty śpiwasz sobie

i ja poczynam także o twej robić dobie.

Rano, w południe, $w$ wieczór ty śpiewasz, ja orzę.

Dobranoc, mój śpiewaku, czarne wstają zorze.

w. 11 Rubakier - kierować na lewo, w lewą stronę (ze słownictwa flisackiego).

$\dot{z} y z n e j$ flocie - chodzi o fale rzeki niosące plony.

w. 11-12 Mowa o wiosennym spływie zboża do Gdańska.

w. 12 dar za dar we złocie - sens: transakcja wymiany złotych monet za złoto zboża; nawiązanie do przysłowia „Dar za dar, darmo nic” (Krzyżanowski, 1969-1972: „dar” 7) oraz łacińskiej maksymy „do ut des” - „Daję, abyś (i ty mi) dał”, wyrażającej zasadę wzajemnego świadczenia posług, dobrodziejstw (Michalunio, 2007, s. 132).

w. 13 Oracz ziemię rznie pługiem - por. Sobótka 12 (Kochanowski, 1997, s. 110, w. 17): „Oracz pługiem zarznie w ziemię".

w. 14 Płodu Cecerzynego - zboża; od Ceres (gr. Demeter) rzymskiej bogini urodzaju pól, przedstawianej w ikonografii z kłosami w rękach.

na oddanie wierzy - wierzy w zwrot ziarna przez ziemię, mowa o nowych plonach.

w. 15 rozczyna gorgi - zaczyna trele, śpiew.

w. 16 Tytyr - konwencjonalne imię pasterza; postać Tytyra przywoływana jest w utworach, m.in.: Ekloga I (Publiusz Wergiliusz Maro, 1953, s. 3-9) oraz (4) Rocznica (Gawiński, 2007, s. 34-40).

żenie - tu: gna, wygania.

ugorowe morgi - ziemia nieuprawiana w danym roku, zwykle zarosła trawą; morga - historyczna jednostka powierzchni rolnej wynosząca ok. 0,5 ha.

w. 17 Mowa o nacinaniu brzóz, by uzyskać słodki sok.

żadanej - wybranej.

ostra stala plagi - mowa o płazowaniu, uderzaniu ostrym narzędziem nie wprost, by nie obalić drzewa, lecz tylko naciąć korę.

w. 18 lagi - miara objętości dla płynów.

w. 19 satyrowie - towarzysze Dionizosa zazwyczaj przedstawiani jako pół ludzie, pół zwierzęta (kozły lub konie), skłonni do zabawy.

w. 20 Pan - opiekuńcze bóstwo lasów, wchodził w skład orszaku Dionizosa, pełnił rolę żartobliwego skoczka, śpiewaka.

różek - mowa o instrumencie muzycznym.

w. 24 kłaść na czoło - zdobić głowę wiankami.

\section{Maius. Maj}

w. 1 Flora - rzymska bogini roślinności, siła życiodajna. Na jej cześć odbywały się święta - floralia, które trwały od 28 kwietnia do 3 maja.

w. 3 różańce - tu: kwatery w ogrodzie obsadzone różami, rosaria.

w. 7-8 pod krzakiem roży / Wenus z pięknym Adonem swe pieszczoty mnoży - tu: róża jako kwiat Wenus, symbol miłości. Wenus, rzymska bogini miłości, uwiodła pięk- 
nego młodego łowcę Adonisa. Razem w siedzibie bogini (na wyspie Cypr lub Cytera - zależnie od wersji mitu) spędzali większą część roku, ciesząc się swoim towarzystwem. Młodzieniec został zabity przez dzika podczas polowania, z łez rozpaczy Wenus za ukochanym wyrosły białe róże, a z jego krwi - anemony.

w. 9 Stońce, Wenus - poeta utożsamia życiodajną siłę słońca z miłością (Wenus). lubem - miłym, przyjemnym.

w. 10 przyrodzonym - naturalnym.

w. 11 źrzedlnic - źródeł.

W. 13 wśnieg bielsza cera - bielszą od śniegu, por. Ps 51, 9. cera - skórą, karnacją.

w. 14 dziedziczki hyblejskie - pszczoły; Hybla - góra na Sycylii, znana z kwiatów tymianku oraz obfitości pszczół, pochodził stamtąd słynny miód hyblejski sławiony przez poetów, m.in. Teokryta.

w. 15 Wilaneczki - dziewczęta wiejskie (z wł. villanesca). nowinki zielone - nowalijki, warzywa zbierane wiosną.

w. 16 kształciki upstrzone - kolorowe gorsety, ciasno wiązane na tułowiu.

w. 19 Boże, tu cuda Twoje, tu Twe wielkie dziwy - por. (37) Na dom w Czarnolesie (Kochanowski, 1957, s. 133), w. 1: „Panie, to moja praca, a zdarzenie Twoje”.

w. 21 z oceana - tu: z wielkiego morza; od mitologicznego Okeanosa - greckiego uosobienia wód otaczających świat.

\section{Iunius. Czerwiec}

w. 1 Chrzciciel święty Jan... chrzci - mowa tu o obrzędzie święcenia wody, który ma miejsce 23-24 czerwca, czyli w wigilię św. Jana Chrzciciela. Możliwe również, że jest to nawiązanie do licznych przysłów wiążących postać św. Jana Chrzciciela z opadami deszczu, zob. (Krzyżanowski, 1969-1972: „Jan św. Chrzciciel”). nowiny - rola uprawiana po raz pierwszy lub od niedawna.

w. 2 pierwociny - tu: pierwsze zbiory, plony.

w. 5 Dyjanna - Diana, rzymska bogini utożsamiana z gr. Artemidą; patronka dziewic, łowów, przyrody i płodności.

w. 7 Akteona - Akteon był mitycznym myśliwym, który podglądał nagą Dianę podczas kąpieli.

w. 7-8 się sam pali, / Po niebieskiej Feb tocząc wóz ognisty sali - sam Febus płonie z pożądania (oglądając z nieba nagą Dianę), powożąc rydwanem Słońca po nieboskłonie. Febus - z gr. Fojbos jaśniejący, czysty; przydomek nadawany Apollinowi jako bogu słońca.

w. 9-10 Wzwodza... / Na świat - tu: wydają na świat.

w. 9 maluty - malutki; mowa o pisklętach.

w. 10 maciorki - samiczki.

piórkami niezsuty - nieupierzony.

w. 11 A drugie się gotuja - a inne ptaki przygotowują się (do wyprowadzania młodych z gniazd). 
w. 11-12 Feniks... / ... w wiek... w słonecznym ma ołtarzu chrzciny - mityczny ptak, który ginął w płomieniach w swoim gnieździe co pięćset lub tysiąc lat, by odrodzić się z popiołów. Określenie $w$ wiek ma tu charakter ogólny, poeta pisze o długim czasie. w. 13 brzaski Lucyferowe (Fosforos, Heosforos) - Gwiazda poranna, dosł. „niosąca światło". Jest to nazwa planety Wenus, widać ją najdłużej ze wszystkich gwiazd przed wschodem Słońca.

późne Hespery - nimfy (Hesperydy) zachodzącego Słońca; ogród Hesperyd znajdował się na zachodzie Europy, w pobliżu Cieśniny Gibraltarskiej.

w. 15 gorgi-zob. objaśnienie do Kwiecień, w. 15.

w. 15-16 Sens: humorystycznie o krakaniu wron, gawronów i nieprzyjemnym, zgrzytliwym głosie pawia (ptak złotookiej forgi).

w. 16 forgi-pióropusza.

w. 17 łąk... postrzyżyny - koszenie łąk.

w. 19 Nie tylko złoto w cenie - aluzja do mitu o Parysie, który miał podarować złote jabłko najpiękniejszej bogini i otrzymać w zamian miłość pięknej Heleny. podczas - niekiedy, czasem.

w. $20 \quad$ zacz jest - jest tym.

nadobna - miła, piękna.

w. 21 sobótki - przesilenie letnie przypadające na noc z 23 na 24 czerwca (czyli w wigilię św. Jana Chrzciciela). Nazwą tą określa się obrzędy przeprowadzane tej nocy, które mają na celu zapewnienie zdrowia ludziom i zwierzętom oraz bogate plony. Podczas sobótki młodzież tańczy przy ognisku, dziewczęta rzucają wianki na wodę.

w. 23-24 Mowa tu o próbie usunięcia sobótki przez księży katolickich, którzy uznawali święto za pogańskie i rozpustne. Autor apeluje do czytelnika, by zachować wieloletnią tradycję. Apologię sobótki, przeciw próbom jej zniesienia, głosił m.in. Kochanowski (1997, s. 90-91, w. 9-20; zob. też Mazurkiewicz, 1993, s. 128-129).

\section{Iulius. Lipiec}

w. 1 żeńców - żniwiarzy.

w. 2 zboże dostało - dojrzało, obfituje.

w. 3 Oluchna... przyśpiewuje - aluzja do pieśni Oluchny, por. (18) Żeńcy (Szymonowic, 2000, s. 163-174).

w. 7 Tytyr - zob. objaśnienie do Kwiecień, w. 16. skumli - żałośnie błaga, prosi natrętnie, żebrze.

w. $8 \quad$ luto - rzewnie, smutnie.

na brzęczacej drumli - na ludowym instrumencie muzycznym szarpanym.

w. 9 Zboże pory dostawa - zboże jest dojrzałe, nadaje się do żniw. kordele - krótką broń białą (kordelas), używaną przez myśliwych do dobijania zwierzyny.

w. 9-10 Żartobliwe nawiązanie do przysłowiowej frazy biblijnej: „conflabunt gladios suos in vomeres”, „miecze przekuwać na lemiesze” (Iz 2, 4; por. Mi 4, 3), mowa o usta- 
niu czasu wojny i nadejściu okresu obfitości, pokoju (zob. Krzyżanowski, 19691972: „miecz” 12).

w. 13 równianki - wieńce, wiązanki; splot ozdobnych liści, kwiatów i owoców.

w. 14 kmiecianki - chłopki.

w. 15 dostałe siecze siana - kosi dojrzałą trawę.

w. $16 w$ bróg - bróg to ruchomy daszek, służący do ochrony stogu siana lub zboża.

w. 17 bukowe cienie - element sztafażu charakterystycznego dla antycznej sielanki; buk występuje w okolicach Krakowa, gdzie mieszkał Gawiński.

w. 18 Dameta z Likoryda - konwencjonalne imiona pasterzy, bohaterów sielanek zob. m.in. Ekloga III (Publiusz Wergiliusz Maro, 1953, s. 9-18), (6) Mopsus (Szymonowic, 2000, s. 41-51), (4) Rocznica (Gawiński, 2007, s. 39, tu w. 159-160).

żenie - gna, wygania.

w. 19-20 Sens: za ucztę (bankiety) służą pasterzom pisklęta z gniazd, zaś za deser (wety) zapewne owoce leśne.

w. 20-21 bankiety / Sobie stroją, a potym $w$ las ida na wety - robią sobie uczty, a potem idą do lasu na „deser” (zob. objaśnienie do w. 23-24).

w. $21 \quad$ wdzięcznym - pięknym.

$z$ upału dwojego - z powodu podwójnego upału: słońca i pożądania.

w. 22 drzewa labiryntowego - drzewa liściastego (różnych gatunków), z którego formowano labirynty w barokowych ogrodach.

w. 23 ucztach fruktowych - ucztach owocowych; być może nawiązanie do staropolskiego weselnego obyczaju uczty cukrowej, którą nowożeńcy spożywali tuż przed pokładzinami, w sypialni.

w. 24 uszczknać pozwala jagodki - tj. pozwala pocałować się w policzek lub skosztować owocu (dziewictwa); gra znaczeniami słowa jagoda.

\section{August. Sierpień}

w. 1 Kopy gęste... jak gwiazdy - zboże ułożone w liczne stogi (gęste jak gwiazdy na niebie); mowa o urodzaju.

w. 2 do Gdańska - mowa o przyszłej sprzedaży zboża w Gdańsku, po spławieniu go Wisłą.

w. 3 giermak - długa suknia wierzchnia, sukmana.

w. 5-8 Por. (18) Żeńcy (Szymonowic, 2000, s. 165):

Słoneczko, śliczne oko, dnia oko pięknego,

Nie jesteś ty zwyczajów starosty naszego.

Ty dzień po dniu prowadzisz, aż długi rok minie,

A on wszystko porobić chce w jednej godzinie.

Ty czasem pieczesz, czasem wionąć wietrzykowi

Pozwolisz i naszemu dogadzasz znojowi,

A on zawsze: „Pożynaj, nie postawaj” - woła,

Nie pomniąc, że przy sierpie trójpot idzie z czoła.

(w. 31-38)

w. 8 Pożynaj - zżynaj, ścinaj zboże (sierpem). 
w. 10 do gumien - do stodół.

przestronych - obszernych, dużych.

w. 11-12 na to swe żniwo / Przyjechawszy do miasta - mowa o transakcji kupna-sprzedaży zboża przez chłopa.

w. 12 siecze - tu: pije.

w. 16 praw sobie $i$ komu by - by był w zgodzie z sumieniem, obyczajami.

niecha - zaniecha, zrezygnuje z czegoś.

w. $17 \quad w$ winohradach $-\mathrm{w}$ winnicach.

w. 18 barwica - barwa.

w. 19 grzeczny - uprzejmy, miły.

w. 19-20 Aluzja do mitu o Parysie, który miał wręczyć złote jabłko najpiękniejszej bogini. O ten tytuł ubiegały się: Hera, Atena i Afrodyta. Każda z nich próbowała go przekonać, oferując mu dary: Hera - władzę nad Azją, Atena - sławę i zwycięstwo w każdej walce, a Afrodyta - miłość najpiękniejszej kobiety, Heleny. Parys wręczył jabłko trzeciej bogini.

w. 21 Ceres - tu: metonimia zboża; zob. objaśnienie do Kwiecień, w. 14.

w. 23-24 Mowa o dożynkach, podczas których dziękowano za obfite plony, śpiewano i ucztowano. Ważnym elementem obchodów jest wieniec dożynkowy pleciony z kłosów zboża, kwiatów i gałązek, wręczany gospodarzowi (panu).

w. $24 \quad p<r z y>$ bębenku - prawdopodobnie: przy wtórze rytmu wygrywanego na bębnie.

\section{September. Wrzesień}

w. 1 Pożąłeś - zob. objaśnienie do Sierpień, w. 8.

w. 1-2 Por. (10) Życia dworskiego, miejskiego a wiejskiego, ziemiańskiego paralela (Gawiński, 2007, s. 72):

Wieś z niebem handel wiedzie bez zgryźliwej troski pana swego, bo opiek z nim spółkuje Boski co da ziemi, stokrotnie ta mu nazad wraca; na taki zysk sama się ludziom wmawia praca.

(w. 47-50)

w. 3 czujna - tu: przezorna, zapobiegliwa.

w. 3-4 jako siła / Zjada rok - jak wiele potrzeba żywności w ciągu roku.

w. 4 sięzłożyła - przeciwstawiła się (niedostatkowi).

w. 5 Sforz - nakładaj psom sforę, czyli rzemień lub smycz do prowadzenia. da charci w pole - wyprowadź charty na polowanie. kocie - określenie zająca w żargonie myśliwskim.

w. 5-6 kocie / ... gra tu idzie o cie - uciekaj (uważaj) zającu, idzie tu o twoje życie. Nawiązanie do przysłowia „Wara kocie, idzie o cię” (Nowa księga przysłów i wyrażeń przysłowiowych polskich nie odnotowuje).

w. $7 \quad k o z \dot{u} c h-$ sierść. 
w. 7-8 przepiórka / Krogulcowi swe daje testamentem piórka - mowa o polowaniu z krogulcem (ptakiem drapieżnym) na przepiórki. Aluzja do podobieństwa upierzenia obydwu ptaków.

w. $10 \quad$ łacno - łatwo.

w. 11 wiernego - w domyśle: wiernego sługę.

w. 13 Oceana - zob. objaśnienie do Maj, w. 21.

w. 14 ćmami - chmarą, ciżbą.

w. $16 \quad c z e l a d k a-$ służba, domownicy, także dzieci.

w. 17-18 aluzja do biblijnej Księgi Rut (Rt 2, 15-16), w której mowa o zwyczaju pozostawiania kłosów na polu, by biedne kobiety mogły je zebrać.

w. 19 przecię-jednak.

w. 20 matce - prawdopodobnie: naturze.

w. 21 Rajskie jabłka - tj. dorodne, piękne, kuszące (zob. Rdz 3, 6). winniczne purty - mowa o małych, kwaśnych jabłuszkach dzikiej jabłoni leśnej japurty. Jej owoce przeznaczano na ocet winny.

w. 21-22 Mowa o sprzedaży części owoców oraz plonów do miasta i chowaniu drugiej części do spiżarni zamkniętej na klucz (zamczyste furty).

w. 23-24 Sens: purpurowe jabłka i ocet winny są towarami luksusowymi, które ozdabiają pańskie stoły.

w. $24 \quad$ cukrowymi... masy - wety, desery.

w. 21b Marsowym tańcem dochodza potrzeby - marsowe potrzeby - wojna; sens: zboże jest już zebrane, więc można wznowić walki na polach.

w. $24 \mathrm{~b}$ adherenty - zwolennicy, stronnicy.

\section{October. Październik}

w. 1-2 Mowa o siewie oziminy, który zgodnie ze staropolską tradycją powinien zakończyć się jeszcze we wrześniu.

w. $2 \quad z$ płatem - z zapłatą. sowitem - zob. objaśnienie do Wrzesień, w. 2.

w. 4 nawiedzając-odwiedzając.

w. $5 \quad$ Cyt - tu: cisza.

w. 7 po kiermasiech, które gęste święca - na kiermaszach, których wiele, są one okazją do świętowania.

w. 14 ćma - zob. objaśnienie do Wrzesień, w. 14.

Auster - (Notos) uosobienie wiatru południowego.

dma - zob. objaśnienie do Luty, w. 14.

w. 15 oczupasach - przepychu, wspaniałości.

w. 17 nową Jutrzenkę - mowa o Matce Boskiej, której poświęcony jest październik jako miesiąc różańcowy.

w. 18 męża nauk świętych z królewskimi berły - aluzja do św. Jana Kantego; królewskie berła są w herbie Akademii Krakowskiej, gdzie Jan Kanty był profesorem. 
w. 19-20 Mowa o beatyfikacji dwóch świętych, patronów Polski: św. Stanisława Kostki, która miała miejsce w 1602 roku, oraz Jana Kantego, która odbyła się w 1680 roku. Wspomnienie św. Stanisława Kostki przypada na 13 listopada, Jana Kantego 20 października.

w. 21 Schodź z pola z swym warsztatem Marsie, bo już ziębi - mowa o zawieszaniu sporów wojennych na czas zimy.

Marsie - zob. objaśnienie do Marzec, tytuł.

w. 22 płaczorody - pobudzający do płaczu (deszczu).

w. 23-24 Mowa o okresie burz, deszczy.

w. 23 Saturn - (gr. Kronos) italski bóg rolnictwa, uczył ludzi uprawy roli i winnej latorośli, w ikonografii przedstawiany jest $\mathrm{z}$ sierpem lub nożem $\mathrm{w}$ ręce.

Plejadami - zachód Plejad (na początku listopada) zwiastuje początek okresu burzowego. Plejady - siedem sióstr, które Zeus przemienił w konstelację gwiezdną. Według jednej wersji mitu myśliwy Orion, zobaczywszy Plejady w Beocji, zapłonął do nich namiętnością i ścigał je przez pięć lat. Zeus, z litości nad nimi, umieścił je na nieboskłonie.

z mokrym Oryjonem - z niosącym deszcze gwiazdozbiorem Oriona. W mitologii był to syn Posejdona, olbrzym, myśliwy, którego zabił skorpion nasłany przez Artemidę. Orion i skorpion zostali przemienieni w gwiazdozbiory.

\section{November. Listopad}

w. 1 piękności zwierzchnie - piękno powierzchowne, materialne, przemijające.

w. 2 mierzknie - zachodzi.

w. 5 chaje - nawałnice, sztorm.

w. $8 \quad$ kuma - powinowata, krewna, również sąsiadka.

przy wiejskiej wijoli - przy dawnym instrumencie smyczkowym przypominającym budową skrzypce.

w. 9 Wszyscy święci - aluzja do dnia Wszystkich Świętych (1 listopada). kolęd - darów, upominków.

w. 11-12 święty Marcin zwłaszcza, / Co ubogim rznąć z siebie nie żałował płaszcza - nawiązanie do legendy hagiograficznej o legioniście rzymskim z Galii, Marcinie (317 lub 335-397), który okrył połową swojego płaszcza biedaka proszącego o jałmużnę. Następnej nocy objawił mu się Jezus ubrany w jego płaszcz, mówiący aniołom o czynie młodzieńca. Po tym widzeniu Marcin nawrócił się, przyjął chrzest, później został biskupem w Tours. Jego święto przypada 11 listopada.

w. 13-16 Mowa o Dniu Zadusznym (2 listopada), gdy wierni kościoła katolickiego modlą się za dusze czyśćcowe.

w. 17-19 Dzień św. Marcina, 11 listopada, był czasem pieczenia gęsi i wróżb świętomarcińskich (m.in. z wnętrzności gęsi). Tradycja ta ma potwierdzenie w utworach literackich, np. w Gęsi świętego Marcina albo pierwszej kolędzie (1630) Kaspra Twardowskiego i w przysłowiach: „Święto Marcina dużo gęsi zarzyna” (Krzyżanowski, 
1969-1972: „Marcin św.” 25) oraz: „Wesele Marcina: gęś i dzban wina” (Krzyżanowski, 1969-1972: „Marcin św. 32).

w. 21-22 ćmy... /... naturom nieprawe - mgły, wilgoć niezdrowa dla człowieka.

\section{December. Grudzień}

w. 1-3 Nawiązanie do wersetów z proroctwa Izajasza o narodzeniu Mesjasza, zob. Iz 53, 1-2. w. 3-4 To wszystko przechodzi, / Gdy czysta Panna Boga, córka Ojca rodzi - sens: cuda profecji mesjańskiej Izajasza są niczym w porównaniu z wcieleniem Boga.

w. 6 noc największq rodze - mowa o przesileniu zimowym 21 grudnia.

w. 11 domowy z Wulkanem lar.. odpór daja - szyk przestawny, sens: domownicy wraz z bóstwami opiekuńczymi domu dają odpór zimnu, paląc w piecach.

Wulkan - (gr. Hefajstos) rzymski bóg ognia, kowalstwa, metalurgii. lar - mityczny opiekun domostwa, łac. lares familiares - strażnicy domu.

w. 22 przyjść - tu: dożyć.

w. 24 wiek - rok, czas.

\section{Bibliografia podmiotowa}

12 miesięcy opisanie i znaki każdego w tym roku nowym (1753) (1975). W: B. Baczko, H. Hinz (oprac.), Kalendarz pótstuletni 1750-1800 (s. 45-47). Warszawa: Państwowy Instytut Wydawniczy.

Obserwacje niektóre, co w którym miesiącu, tak względem zdrowia, jak względem gospodarstwa, uważać i zachować, wierszem krótko położone (1760) (1975). W: B. Baczko, H. Hinz (oprac.), Kalendarz półstuletni 1750-1800 (s. 61-64). Warszawa: Państwowy Instytut Wydawniczy.

Gawiński, J. (2000). Z chłopki księżna. Historia wielkiej mistyfikacji z XVII wieku. Jan Gawiński „Mowa ostatnia umierajacej przez miecz Jadwigi z Kolbuszowa [...]”. Oprac. D. Chemperek. Lublin: Wydawnictwo Uniwersytetu Marii Curie-Skłodowskiej.

Gawiński, J. (2003). Clipaeus Christianitatis to jest Tarcz chrześcijaństwa. Oprac. D. Chemperek, W. Walecki. Kraków: Collegium Columbinum.

Gawiński, J. (2005). Dworzanki albo Epigrammata polskie. Wyd. J. Głażewski. Warszawa: Instytut Badań Literackich PAN, Wydawnictwo Stowarzyszenie „Pro Cultura Litteraria”.

Gawiński, J. (2007). Sielanki z Gajem zielonym. Wyd. E. Rot. Warszawa: Instytut Badań Literackich PAN, Wydawnictwo Stowarzyszenie „Pro Cultura Litteraria”.

Gawiński, J. (2009). Pieśni. Wyd., oprac. D. Chemperek. Warszawa: Wydawnictwo Neriton.

Jana z Wielomowic Gawińskiego Pisma pozostałe (1879). Wyd. W. Seredyński. Kraków: Drukarnia „Czasu”.

Kochanowski, J. (1957). Fraszki. Oprac. J. Pelc. Wrocław: Zakład Narodowy im. Ossolińskich.

Kochanowski, J. (1997). Pieśni. Oprac. L. Szczebińska-Ślęk. Wrocław: Zakład Narodowy im. Ossolińskich.

Pismo święte Starego i Nowego Testamentu w przekładzie polskim w.o. Jakuba Wujka S.J. (1962). Tekst poprawili ks. S. Styś, W. Lohn. Kraków: Wydawnictwo Apostolstwa Modlitwy.

Publiusz Wergiliusz Maro (1953). Bukoliki i Georgiki. Przeł., oprac. Z. Abramowiczówna. Wrocław: Zakład Narodowy im. Ossolińskich. 
Rudomicz, B. (2002). Efemeros, czyli Diariusz prywatny pisany w Zamościu w latach 1656-1672. Cz. 1-2. Przeł. W. Froch, oprac. M.L. Klementowski, W. Froch, Lublin: Wydawnictwo Uniwersytetu Marii Curie-Skłodowskiej.

Staropolska poezja ziemiańska. Antologia (1988). Oprac. J.S. Gruchała, S. Grzeszczuk. Warszawa: Państwowy Instytut Wydawniczy.

Szymonowic, Sz. (2000). Sielanki i pozostałe wiersze polskie. Oprac. J. Pelc, Wrocław: Zakład Narodowy im. Ossolińskich.

Włodarski, M. (oprac.) (1997). Polska poezja świecka XV wieku. Wrocław: Zakład Narodowy im. Ossolińskich.

\section{Bibliografia przedmiotowa}

Barłowska, M. (2014). „Nasz Kochanowski”. Studia z recepcji poety w wieku XVII. Katowice: Wydawnictwo Uniwersytetu Śląskiego.

Bystroń, J.S. (1994). Dzieje obyczajów w dawnej Polsce. Wiek XVI-XVIII. T. 1-2. Warszawa: Państwowy Instytut Wydawniczy.

Chemperek, D. (2005). Poezja Jana Gawińskiego i kultura literacka drugiej połowy XVII wieku. Lublin: Wydawnictwo Uniwersytetu Marii Curie-Skłodowskiej.

Dziama, L. M. (1905). Jan Gawiński. Studium literackie. Kraków: Księgarnia D.E. Friedleina.

Głażewski, J. (2008). W żywiole tekstu. „Dworzanki” Jana Gawińskiego - próba lektury i interpretacji. Warszawa: Instytut Badań Literackich PAN.

Juszyński, M.H. (1820). Dykcjonarz poetów polskich. T. 1. Kraków: Drukarnia Józefa Mateckiego.

Kiliańczyk-Zięba, J. (2015). Wstęp. W: Stanisław z Bochnie Gąsiorek, Fortuna albo Szczęście (s. 37-41). Oprac. J. Kiliańczyk-Zięba. Kraków: Wydawnictwo Uniwersytetu Jagiellońskiego.

Kroczak, J. (2008). Szymon Szymonowic i Jan Gawiński a magicznie zadawana impotencja. W: R. Krzywy (red.), Erotyzm w literaturze staropolskiej (s. 49-63). Warszawa: Wydawnictwa Uniwersytetu Warszawskiego.

Krzyżanowski, J. (red.). (1969-1972). Nowa księga przysłów i wyrażeń przysłowiowych polskich. T. 1-3. Warszawa: Państwowy Instytut Wydawniczy.

Kuchowicz, Z. (1992). Człowiek polskiego baroku, Łódź : Wydawnictwo Łódzkie.

Mazurkiewicz, R. (1993). Tradycja świętojańska w literaturze staropolskiej. Kraków: Wydawnictwo Naukowe WSP.

Michalunio, Cz. (oprac.) (2007). Dicta. Zbiór łacińskich sentencji, przysłów, zwrotów, powiedzeń. Z indeksem osobowym i tematycznym. Kraków: Wydawnictwo Naukowe WSP.

Nowicka-Jeżowa, A. (1988). Homo viator - mundus - mors. Warszawa: Wydawnictwa Uniwersytetu Warszawskiego.

Nowicka-Jeżowa, A. (1992). O staropolskiej poezji żałobnej. Warszawa: Wydawnictwo Naukowe PWN.

Piskała, M. (2010). Arkadyjskie echa w epigramatyce staropolskiej. W: J. Dąbkowska-Kujko, J. Krauze-Karpińska (red.), Staropolskie Arkadie (s. 99-112). Warszawa: Instytut Badań Literackich PAN, Wydawnictwo Stowarzyszenie „Pro Cultura Litteraria”.

Piszczykowski, M. (1977). Wieś w literaturze polskiego baroku. Wrocław: Zakład Narodowy im. Ossolińskich.

Rot-Buga, E. (2009). Bukoliczna księga znaczeń. Problemy interpretacji i edycji „Sielanek” Jana Gawińskiego. Warszawa: Wydawnictwo Stowarzyszenie „Pro Cultura Litteraria”. 
Rot-Buga, E. (2013). „Helikon” Jana Gawińskiego - glosa edytorska. Roczniki Humanistyczne, 11 (1), 7-25.

Sproede, A. (1990). Gawiński’s Einspruch. Jan Kochanowski's „tragische” Fraszka I, 3 ( „O żywocie ludzkim") in einer Leseart der Barockzeit. Russian Litterature, 27 (2), 157-196.

Walińska, M. (2003). Mitologia w staropolskich cyklach sielankowych. Katowice: Wydawnictwo Gnome.

Wojtowicz, W. (2010). Między literatura a kulturą. Studia o „literaturze mieszczańskiej” przełomu XVI i XVII wieku. Szczecin: Wydawnictwo Naukowe Uniwersytetu Szczecińskiego.

Zajdler, L. (1977). Dzieje zegara. Warszawa: Wydawnictwo Wiedza Powszechna.

\section{The critical edition of the poem "Miesięcy dwunastu z swoich okoliczności opisanie" by 17-century author Jan Gawiński}

\section{Summary}

The critical edition of the poem "Miesięcy dwunastu z swoich okoliczności opisanie" by 17-century author Jan Gawiński (approx. 1622-1684) is the first academic work on the poem. Twelve poems are dedicated to twelve months. The author presents nature, work in the field and farm, religious and pagan ceremonies performed at the time in the Polish countryside, from a perspective of a Baroque classicist. He links erudition (e.g. references to Vergilius, Jan Kochanowski, Szymon Szymonowic) with observations and often humour. The publication includes an introduction that provides the reader with a historical background and context to the piece, the description of the sources, translation, and editorial notes.

Słowa kluczowe: Jan Gawiński, edycja krytyczna, barok, poemat cykliczny, klasycyzm barokowy

Keywords: Jan Gawiński, critical edition, Baroque, Cyclic poem, Baroque Classicism 